\title{
Operation of Educational Software in the Process of Teaching Natural Sciences in Lithuanian Comprehensive School
}

\author{
Palmira PEČIULIAUSKIENĖ, Marija BARKAUSKAITĖ \\ Vilnius Pedagogic University \\ Studentu 39, 08106 Vilnius, Lithuania \\ e-mail: palmira.p@post.skynet.lt,edukologija@vpu.lt
}

Received: March 2005

\begin{abstract}
On the basis of national research data on schoolchildren' achievements, the article deals with implementation of educational software in the process of teaching world study in primary school and different natural sciences in basic school. It has been established that educational software is often enough implemented during the classes on world study in primary school in comparison with natural science lessons provided in basic school. Primary educational software is regularly used in the city site, less frequently - in the regional centre and rarely in the rural area schools. On the opposite of the city site schools, basic educational software is widely employed in the rural area. The comparison of the rates of implementation of educational software during the different classes on natural sciences reveals that educational software is most frequently applied during the classes on biology, the least frequently - during the classes on physics.
\end{abstract}

Key words: information technology, educational software, primary school, basic school, world study, natural science education.

\section{Introduction}

Substantial changes in public and social life took place in Lithuania as well as in other Baltic states at the beginning of the last decade of the 20th century. They conditioned the fundamental educational alterations including educational reform which was aimed at creation of a new modern education system. One of the features of the latter is a flexible and overall operation of information technology ${ }^{1}$ in the teaching/learning process. Integration of the latest information technology is a crucial component of fundamental educational alterations that closely combine school education with economy, public and social life and culture (Owen, 1999; Holmes, Savage and Tangney, 2000; Mooij and Smeets, 2001).

\footnotetext{
${ }^{1}$ The concept Information Technology involves environment related to the human an organizational aspects a computer in which is the key element. The other concepts including educational softwares, computers, the latest technologies have a narrower meaning and are used interchangeably in the article: in all cases they have the most general meaning of the concept information technology.
} 
Information technology integration into educational practice is very wide and embraces a number of fields the computers in which are applied as a means of teaching, communication etc. (Anderson and Collis, 1993; Hakkarainen, Ilomäki, Lipponen, Muukkonen, Rahikainen, Tuominen, et al., 2000; Pelgrum, 2001). The following trends can be marked when summarizing the variety of information technology operation into educational practice: 1) learning about the computer; 2) learning from the computer; 3) learning with the computer (Jonassen, 1996).

Conceptual verification of the information technology integration process into educational practice passes through four stages: initial, operation, integration and alteration (UNESCO, 1994). The initial stage focuses on computers and software. The next stage involves practical operation of information technology in the majority of educational subjects. A number of countries worldwide are still in this stage - a part of them have just entered, the others - have nearly finished it (UNESCO, 2002). The third stage embraces practical operation of information technology in all educational subjects. Learning in the last stage becomes a continuous process and public position on learning changes (Dagiené, 2004). The above mentioned stages of information technology integration are characteristic of educational practice in schools and other establishment institutions of all countries.

On the basis of the results of national research on schoolchildren' natural science literacy (Research on Implementation and Operation of Computer-Based Teaching Aids, 2003), the article deals with the second stage regularities in information technology integration into the educational practice of natural sciences concerning the following factors: a concentre of comprehensive school (primary school, basic school), school status agreeably to the location (city site, regional centre, rural area), different natural sciences (physics, chemistry, biology). The obtained results are compared with the previously acquired data of other national research. The revealed national second stage regularities in information technology operation are compared with the regularities established in other Baltic States (Kurm, 2003; A. Kangro and I. Kangro, 2004). The choice of comparison has been determined by very similar evolution of public life and education system of the Baltic States as public and social alterations and thus changes in education system took place in these countries in the last decade of the 20th century.

\section{Review on the Carried out National Research on Information Technology Implementation in Educational Practice}

Information technology implementation in the educational process can positively influence schoolchildren's results provisions and their communication with teachers and peers (Means et al., 1993; Fountain and Thomson, 2001; Pelgrum, 2001; Ainley, Arthur, Macklin and Rigby, 2003).

Information technology in educational practice in Lithuania started to operate at the end of the 9th decade of the 20th century. In the initial stage, close attention was devoted to computers and software. After the start of computerization, computer equipment at 
school was supposed to have been the main idea. The results of the first stage of information technology were summarized in the first international research Information Technology at School conducted in 1997-1999 / SITES M1 (Second Information Technology in Education Study). This research is undertaken by the IEA (International Association for the Evaluation of Educational Achievement).

The international study SITES M1 tried to clarify the level of school computerization as well as the situation on how information technology operated in different concentres of comprehensive school - basic and secondary school. After Lithuania joined this international investigation, a refusal to examine how information technology operated in primary school in terms of insufficient computer supply was taken into consideration (Markauskaite, 2000). Therefore, the study SITES M1 in Lithuania was pursued only in basic and secondary school.

The second stage of the study (SITES M2) took place in 1999-2001. It was qualitative research intended to exhaustively analyze the best examples of information technology and particularly educational software applied in educational practice (Kurilovas, 2003). Educational software is specific application software designed by professional programmers or work-groups (programmer, teacher, psychologist, designer, etc.) and intended to teach single subjects in comprehensive school. According to the purpose of applying it in educational practice, educational software may be divided into demonstrative, modelling, designing, training, electronic course books, etc.

International research in Lithuania was supported by the study of operation and implementation of information technology (2003). It was carried out in schools which had obtained educational software applied for teaching natural science subjects including chemistry (Crocodile chemistry), physics (Crocodile technology), mathematics (Dynamic Geometry) and informatics (Komenskij logo). The investigation revealed insufficient implementation of educational software teaching chemistry, physics, mathematics and informatics. It was established that despite some schools had purchased educational software they employed it very rarely.

Along the above mentioned research on information technology, a few local investigations the authors of which are the teachers of comprehensive and higher schools have been conducted (Giedraitienè-Lileikienè, 2001). The local studies most frequently discuss the didactic aspects of information technology operation.

The survey of literature indicates that the second stage of information technology in educational practice of teaching natural sciences in Lithuanian comprehensive school and the process of this stage in comprehensive schools of other Baltic states has quite a few common features. Research shows that recently information technology in Estonian comprehensive school is applied for teaching informatics as well as other subjects. However, operation of information technology in educational practice of various subjects is not frequent and is used by a small number of teachers. More often educational software is implemented in Estonian primary rather than in basic school (Kurm, 2003). Research carried out in Latvia disclosed the preconditions of insufficient information technology operation in educational practice of the country including lack of specific programs, need of technological and didactic knowledge of program operation, shortage of financial motion (A. Kangro and I. Kangro, 2004). 
A summary of the results obtained from national research (national and international) on information technology operation at institutional level reveals that the studies analysed information technology operation only in two concentres of comprehensive school - basic school and secondary school. However, no analysis of information technology operation in primary school was performed. There is a lack of research on information technology operation in the process of teaching different subjects including natural sciences. No studies of information technology operation in differently located comprehensive schools (city site, regional centre, rural area) are undertaken.

\section{Methodology}

\subsection{Pedagogical and Psychological Preconditions}

Information technology integration into educational practice can be based on the philosophy of various trends and psychological theories that reflect teaching/learning conception, content, purposes and the ways to reach them. Information technology itself is not an insular culture as it can lead to the formation of different cultures and philosophical provisions (Ozmon and Carver, 1996). Most frequently information technology integration into educational practice can be supported by two theories of pedagogical psychology which are behaviourism and cognitive theory which is the basis of the constructive pattern of teaching.

When analyzing operation of educational software in educational practice of teaching natural sciences, the article discusses both psychological trends. On one hand, in terms of behaviourism, operation of educational software is useful in the process of teaching mechanical skills, helps to individualize teaching and ensures cognitive feedback (Gage and Berliner, 1994;). On the other hand, in terms of constructivism, operation of educational software is efficient if helping to apply gained knowledge in different situations, developing thinking abilities at higher level and encouraging the processes of intensive learning (Smeets et al., 1999; Neo, 2003).

\subsection{Instruments of Research}

The results of research (national and international) on information technology operation at institutional level carried out in Lithuania determined the purpose of the study which was to establish the frequency of operation of educational software in educational practice of teaching natural sciences agreeably to the following attributes: a concentre of comprehensive school (primary, basic), school status agreeably to the location (city site, regional centre, rural area), different natural sciences (physics, chemistry, biology).

To achieve the purpose, the database of national research on the 4th and 8th formers' achievements was used (National research on 4th and 8th formers' achievements, 2003).

A pattern of the sample of national research was chosen and the sample itself was performed under the methods applied in international research IEA (International Association of the Educational Achievement). Random sample of schoolchildren was applied 
for the purpose of research. Family random sample was chosen as the principle of sample taking, i.e., all learners not individual students of the same form were randomly sampled to participate in the survey. 2253 fourth-formers from 117 schools and 2717 eighthformers from 124 schools were involved into national sample taking in 2003. National research tried to find out if achievements in mother tongue, mathematics, natural science education and social education corresponded to the requirements imposed in the national General Programmes and Educational Standards. Moreover, national research examined schoolchildren' state of health at school, load of homework, assessment of learning results and employment of new teaching aids in educational practice. One of the latest teaching aids that ensuring the latest teaching methods and styles is computer-based education program.

There is enough data obtained during the process of national research in order to assess the frequency of operation of educational software in educational practice of teaching natural sciences agreeably to the concentre of comprehensive school (primary, basic), school status agreeably to the location (city site, regional centre, rural area), different natural sciences (physics, chemistry, biology). Moreover, information disclosed in the account of research on national schoolchildren' achievements lays down the preconditions to apply the triangulation method, i.e., to compare students and teachers' positions on operation of educational software. The format of operation of educational software was not studied during national research on schoolchildren' achievements, and therefore the article does not deal with this issue.

Seeking to discover the frequency of operation of educational software in educational practice, focus on appropriate school supply with educational software was provided. The study SITES M1 (1998) pointed out that the majority of comprehensive schools (60$80 \%$ ) were provided with educational software applied for exact and natural sciences (mathematics, physics and informatics) while the humanities, social sciences and integrated teaching were devoted scant attention to those. Therefore, this investigation has been based on the analysis of the frequency of operation of educational software in educational practice of teaching natural sciences.

Natural sciences are taught in different types of Lithuanian comprehensive school: primary school (concentre 1, forms 1-4), basic school (concentre 2, forms 5-10) and secondary school (concentre 3, forms 11-12). National research was undertaken in primary and basic school. Thus, our investigation debates the frequency of operation of educational softwares in primary (form 4) and basic (form 8) schools. Primary school (form 4) offers an integrated course in natural sciences called world study. Basic school (form 8) has different natural sciences including physics, chemistry and biology. The national research questionnaire for both forms contained a question about operation of educational software in educational practice of these subjects.

In order to receive 4th and 8th formers' answers to the question in the questionnaire about operation of educational software, national research applied rating measurement. To answer the question, the 4th formers were allowed to choose a single version: frequently, rarely, almost never, never. The 8th formers were also provided a chance to single out one answer: never, rarely, frequently, almost every lesson. The evaluation rating 
'never' was used conducting research in both groups of assessors - primary and basic school. The other versions of rating showed minor differences. Therefore, when comparing the respondents' answers about operation of educational software in different concentres of comprehensive school the answers were presented in the following way: 1) do not operate educational software; 2 ) operate educational software.

\section{Results of Research}

\subsection{Operation of Educational Software in Primary School During the Process of Teaching World Study.}

Having grouped the data provided in the account of national research, rates of operation of educational software in primary school have been established (form 4). In addition, rates of program operation considering school status agreeably to the location (city site, regional centre, rural area) have been confirmed (Table 1 ).

Grouping data indicates that $54.4 \%$ of primary school respondents operated educational software during the classes in world study. The comparison of the operation rates of educational software considering school status agreeably to the location draws that more frequently educational software during the classes in world study is applied in schools of the city site $(56.0 \%)$ and regional centre $(58.2 \%)$ rather that in the rural area $(47.8 \%)$.

\subsection{Operation of Educational Software in Basic School During the Process of Teaching Natural Sciences.}

Operation of educational software in basic school during the process of teaching natural sciences including biology, chemistry and physics has been researched. The data on operation of educational software during the classes in biology, chemistry and physics that was stored in the account of national research on schoolchildren' achievements have been collected. The obtained information has been processed under two features: 1) do not operate educational software; 2) operate educational software. Moreover, the rates of program operation considering school status agreeably to the location (city site, regional centre, rural area) have been confirmed (Table 2).

Grouping data provides that most frequently (41.3\% of the respondents) educational software is applied during the classes in biology while in the group of compared natural

Table 1

Rates of schoolchildren' evaluation of operation of educational software during the classes in world study $(N=2253)$

\begin{tabular}{lcccc}
\hline \multirow{2}{*}{ Operation format } & \multirow{2}{*}{ Complete data } & \multicolumn{3}{c}{ Location } \\
\cline { 3 - 5 } & & City site & Regional centre & Rural area \\
\hline \multirow{2}{*}{ Do not use } & 45.6 & 44.0 & 41.8 & 52.2 \\
Use & 54.4 & 56.0 & 58.2 & 47.8 \\
\hline
\end{tabular}


Table 2

Rates of schoolchildren' evaluation of operation of educational software during the classes in natural science education $(N=2717)$

\begin{tabular}{lccccc}
\hline \multirow{2}{*}{ Subjects } & \multirow{2}{*}{ Operation format } & \multirow{2}{*}{ Complete data } & \multicolumn{3}{c}{ Location } \\
\cline { 4 - 6 } & & & City site & Regional centre & Rural area \\
\hline \multirow{2}{*}{ Biology } & Do not use & 58.7 & 60.1 & 61.4 & 52.3 \\
& Use & 41.3 & 39.9 & 38.6 & 47.7 \\
Chemistry & Do not use & 67.4 & 68.4 & 70.4 & 61.1 \\
& Use & 32.6 & 31.6 & 29.6 & 38.9 \\
\multirow{2}{*}{ Physics } & Do not use & 69.2 & 71.4 & 70.4 & 63.9 \\
& Use & 30.8 & 28.6 & 29.6 & 36.1 \\
\hline
\end{tabular}

sciences such applications are rare during the classes in physics (30.8\% of the respondents).

Research on operation of educational software considering school status agreeably to the location proves that they are more frequently applied during the classes in natural sciences in schools of the rural area rather than in those of the regional center. Rate deviation during the classes in physics is $6.5 \%$, during the classes in chemistry $-9.3 \%$ and during the classes in biology $-9.1 \%$. The rates of operation of educational software during the classes in natural sciences in schools of the city site and regional have only a slight deviation (1-2\%).

\subsection{Comparison of the Results of Operation of Educational Software in Primary and Basic School}

The rates of operation of educational software during the classes in natural sciences in basic school (Table 2) and during the classes in world study in primary school (Table 2) show that in all cases of comparison educational software is more frequently applied during the classes of the latter. There is a single case of evaluation when the rates of their operation in primary school of the rural area $(47.8 \%)$ almost agree with the rates of program operation in basic school of the rural area (47.7\%)

On the basis of rates relative frequency has been calculated. In order to make a comparison of relative frequency of operation of educational software in different concentres of comprehensive school (primary, basic school) and considering school status agreeably to the location (city site, regional centre, rural area), mathematical statistics has been applied - statistical index $t^{2}$ enabling to check statistical significance of relative frequency deviation has been calculated (Table 3). The table presents statistical significance of relative frequency deviation which is marked as follows: ${ }^{* * *}-p<0.001,{ }^{* *}-p<0.01,{ }^{*}$ $-p<0.05$, coloured - deviation is statistically insignificant.

\footnotetext{
${ }^{2}$ the statistical index of relative frequency deviation is calculated under the formula $t=\frac{\left|p_{1}-p_{2}\right|}{\sqrt{\frac{p_{1} q_{1}}{m_{1}}-\frac{p_{2} q_{2}}{m_{2}}}}$ where $p_{1}$ and $p_{2}$ - rates of the compared groups $q_{1}=1-p_{1}, q_{2}=1-p_{2}, m_{1}$ and $m_{2}-$ the number of the respondents in the groups.
} 
Table 3

Statistical indexes of relative frequency deviation and its statistical significance of operation of educational software during the classes in world study and natural science education

\begin{tabular}{lcccc}
\hline \multirow{2}{*}{$\begin{array}{l}\text { Natural } \\
\text { sciences }\end{array}$} & Complete data & \multicolumn{3}{c}{ Location } \\
\cline { 3 - 4 } & $(N=2253 ; N=2717)$ & City site & $\begin{array}{c}\text { Regional centre } \\
(N=911 ; N=1112)\end{array}$ & $\begin{array}{c}\text { Rural area } \\
(N=706 ; N=935)\end{array}$ \\
\hline Biology & $9.8^{* * *}$ & $7.3^{* *}$ & $8.0^{* * *}$ & 0.1 \\
Chemistry & $6.7^{* *}$ & $11.3^{* * *}$ & $12.0^{* * *}$ & $3.3^{* *}$ \\
Physics & $17.2^{* * *}$ & $12.9^{* * *}$ & $12.0^{* * *}$ & $4.3^{* *}$ \\
\hline
\end{tabular}

Calculated statistical significance of relative frequency deviation indicates that only a single case of comparison which is collating of relative frequency of operation of educational software in primary and basic school of the rural area finds it statistically insignificant. In all other cases of comparison deviation of relative frequency remains statistically significant. An initial precondition that educational software is more frequently applied during the classes in world study in primary school is statistically confirmed.

\subsection{Comparison of Operation of Educational Software During the Classes in Different Natural Sciences in Basic School}

The rates of operation of educational software in basic school (Table 2) indicate that educational software is less frequently applied during the classes in physics $(30.8 \%)$ rather than chemistry $(32.6 \%)$ or biology $(41.3 \%)$. The comparison of the rates of operation of educational software during the classes in different natural sciences considering school status agreeably to the location reveals the same regularity: the programs are very rarely applied during the classes in physics and most frequently employed during biology lessons.

In order to statistically validate this regularity, the methods of mathematical statistics have been used, i.e., statistical significance of relative frequency deviation has been calculated. The Tables 4-6 see statistical significance of relative frequency deviation in the following way: ${ }^{* * *}-p<0.001,{ }^{* *}-p<0.01,{ }^{*}-p<0.05$, coloured - a deviation is statistically insignificant.

Table 4

Statistical indexes of relative frequency deviation and its statistical significance of operation of educational software during the classes in natural sciences in the city site schools $(N=1112)$

\begin{tabular}{lccc}
\hline Subjects & Biology & Chemistry & Physics \\
\hline Biology & 0 & $4.1^{* *}$ & $5.7^{* *}$ \\
Chemistry & $4.1^{* *}$ & 0 & 1.5 \\
Physics & $8.1^{* * *}$ & 1.4 & 0 \\
\hline
\end{tabular}


Table 5

Statistical indexes of relative frequency deviation and its statistical significance of operation of educational software during the classes in natural sciences in the regional centre schools $(N=935)$

\begin{tabular}{lccc}
\hline Subjects & Biology & Chemistry & Physics \\
\hline Biology & $\mathrm{x}$ & $4.1^{* *}$ & $4.1^{* *}$ \\
Chemistry & $4.1^{* *}$ & $\mathrm{x}$ & 0.0 \\
Physics & $4.1^{* *}$ & 0.0 & $\mathrm{x}$ \\
\hline
\end{tabular}

\section{Table 6}

Statistical indexes of relative frequency deviation and its statistical significance of operation of educational software during the classes in natural sciences in the rural area schools $(N=670)$

\begin{tabular}{lccc}
\hline Subjects & Biology & Chemistry & Physics \\
\hline Biology & $\mathrm{x}$ & $3.3^{* *}$ & $4.3^{* *}$ \\
Chemistry & $3.3^{* *}$ & $\mathrm{x}$ & 1.1 \\
Physics & $4.3^{* *}$ & 1.1 & $\mathrm{x}$ \\
\hline
\end{tabular}

It has been established that statistical significance of relative frequency deviation of operation of educational software during the classes in physics and chemistry is statistically insignificant in all cases of comparison. However, statistically significant deviation between relative frequencies of operation of educational software during the classes in biology and chemistry and biology and physics has been found in all cases of comparison.

\subsection{Comparison of the Results of Research}

At the time of national research on operation of educational software schoolchildren (group 1 of the respondents) and teachers of natural sciences (group 2 of the respondents, 340 people) were questioned. $39.7 \%$ of the teachers pointed out they never operated educational software in educational practice during the classes in the subject they taught. The comparison of the rates of the teachers and schoolchildren' answers (Table 2) discloses that a lower rate of the teachers agree that they never operate educational software.

The teachers and schoolchildren' answers to the question about operation of educational software during the classes in different natural sciences (physics, chemistry, biology) were received. The slightest differences in operation of educational software have been found between the positions of the teachers of biology and the students. 19\% more teachers than students showed that the programs were applied during the classes in biology. The biggest differences in operation of educational software have been noticed between the positions of the teachers of physics and the learners. 31.5\% more teachers than schoolchildren stated that the programs were employed during the classes in physics.

The results of the latter and the other research (Research on Operation and Implementation of Educational Software; 2003) were compared. The study examined educational 
software designed to teach physics (Crocodile Technology) and chemistry (Crocodile Chemistry). Throughout national research on schoolchildren' achievements, a smaller number of the questioned students commented that educational software was not employed when teaching chemistry and physics (67.4\% and $69.2 \%$ respectively). Meanwhile, research on operation and implementation of educational software explained that 75.8\% of the respondents did not operate the educational software Crocodile Technology during the classes in physics and $71.9 \%$ of the students did not use the educational software Crocodile Chemistry during the classes in chemistry at school.

Deviation between two different results of the study can be clarified by the situation that in the process of research on implementation of educational software only the learners' position on operation of specific educational software obtained by the school and applied in educational practice was analyzed. Meanwhile, throughout national research on schoolchildren' achievements the students' opinion about general operation of educational software not identifying specificity of programs was examined.

\section{Discussion}

The implementation strategy of information technology of Lithuanian education provides aims for operation of educational software in educational practice of comprehensive schools. The main goal is modernization of the educational process that develops students' outstanding abilities such as creativity, learning skills, critical thinking, informative and technological abilities to make life in knowledge society more purposeful. Operation of educational software creates preconditions for renovation of educational content and for employment of the latest methods of teaching and produces a new culture of learning and school life (Ališauskas, Apynis, Brazdeikis, Dagienè, Linkevičiūtè, Markauskaitè, 2004).

The implementation of these goals during the classes in natural sciences in basic school is expressed by the summarized results of research discussed in the article. The rate of operation of educational software in educational practice of natural sciences is not high. $30.8 \%$ of the basic school respondents found them employed in classes in physics, $32.6 \%$ - in chemistry, $41.3 \%$ - in biology.

Operation of educational software during the classes in world study in primary school is conducted more frequently rather than those during the classes in natural sciences in basic school. More than a half of the questioned students of primary school (54.4\%) pointed to operation of educational software during the classes in world study. Difference in operation of educational software in primary and basic school has been statistically confirmed. The achieved result disagrees with technical preconditions of operation of educational software in different concentres of comprehensive school. The computer to students ratio in primary school is 1 to 32 and is higher than that in basic school which is 1 to 19 (Lithuanian education, 2004).

The established tendencies towards operation of educational software in Lithuanian primary and basic school agree with its operation tendencies in the concentres of primary 
and basic school of Estonian comprehensive school. The Estonian primary school learners rather than the students of higher forms more frequently operate educational software (Kurm, 2003).

The comparison of the results of the latter research and the outcomes of other investigations into operation of information technology conducted in Lithuania (Research on Operation and Implementation of Educational Software; 2003) discloses that technical preconditions (computer equipment for schools) do not guarantee successful operation of the programs in educational practice of natural sciences. The researchers from Lithuania as well as from other Baltic states find important the didactic preconditions which are the development of teachers' technological and didactic abilities to apply information technology, concretization of methodology of operation of educational software in the General Programmes and Educational Standards (Dagienè, 2004; A. Kangro and I. Kangro, 2004).

The conclusion of diagnostic research on operation of educational software in educational practice of natural sciences in different concentres of comprehensive school draws that similar tendencies and didactic problems of operation of educational software show up in the second stage of school computerization in Lithuania as well as in comprehensive schools of other Baltic states.

\section{Conclusions}

In terms of the concentre of comprehensive school, research revealed that educational software during the classes in world study in primary school was applied more frequently rather than it was employed during the classes in natural sciences in basic school. Deviation between operation of educational software in primary and basic school has been statistically confirmed.

In terms of the school status agreeably to the location, research disclosed that primary school learners of the city site and regional centre (58.2\%) rather than those of the rural area $(47.8 \%)$ more frequently operated educational software during the classes in world study. The basic school students of the rural area rather than those of the city site and regional centre more regularly use educational software during the classes in natural sciences (physics, chemistry, biology).

The rates of operation of educational software deviate in different classes of natural sciences: most commonly the software is employed in biology classes (41.3\%), less frequently - in chemistry (32.6\%) and the most rarely - in physics (30.8\%).

Having statistically assessed deviation between the frequency of operation of educational software in different locations and school concentres, it has been established that educational software is more frequently applied during the classes in world study in primary school of the city site and regional center rather than during the classes in natural sciences in basic school of the city site and regional center. 


\section{References}

Ainley, J., P. Arthur, P. Macklin and B. Rigby (2003). Thai Learning Technology 2001. Capacity Building of Thai Education Reform (CABTER) - Learning Technologies (Stage 1). Retrieved September 12, 2004, from http://www.onec.go.th/publication/a_tech/sa_tech.htm

Ališauskas, R., A. Apynis, V. Brazdeikis, V. Dagienė, E. Linkevičiūtè, L. Markauskaitè (2004). Informacinių ir komunikacinių technologiju diegimo Lietuvos švietime strategija 2005-2007 metams (in Lithuanian, Strategy for introduction of information and communication technologies into Lithuanian education for 2005-2007). Retrieved January 21, 2004 from

http://www.ipc.lt/21z/naujienos/2004/IKT-strategija09-11.doc

Anderson, E.R., and B. Collis (1993). International assessment of functional computer abilities. Studies in Educational Evaluation, 19, 213-235.

Dagienè, V. (2004) Informaciniu technologijų taikymo švietime konceptualusis pagrindimas (in Lithuanian, Conceptual reasoning of information technologies application in education). Retrieved January 20, 2004, from http://www.leidykla.vu.lt/inetleid/inf-mok/25/str12.html

Fountain, W., and S. Thomson (2001). Backyard wisdom and student insights in developing effective web-supported learning. Conference Proceedings (Short papers), ASCILITE'01: Meeting at the Crossroads. Retrieved September 12, 2004, from http://www.ascilite.org.au /conferences/melbourne01/pdf/papers/fountainw.pdf

Gage, N.L., D.C. Berliner (1994). Pedagogine psichologija. Vilnius, Alna litera (in Lithuanian, Pedagogical psychology).

Giedraitienè-Lileikienè, T. (2001). Informacijos ir komunikacijos technologijų diegimo Kauno m. mokyklose, mokant fizikos, matematikos, informatikos ir ekonomikos, sąsaja su bendrais švietimo ir ugdymo skyriaus darbais. In D. Jurgaitis (Ed.), Fizika, informatika ir matematika bendrojo ugdymo ir aukštojoje mokykloje. Šiauliai, Šiaulių universiteto leidykla (in Lithuanian, Connection of implementation of information and communication technologies in Kaunas schools teaching physics, mathematics, computers and economy with general works of education departments. Physics, informatics and mathematics at schools of general education and institutions of higher education), pp. 107-120.

Hakkarainen, K., L. Ilomäki, L. Lipponen, H. Muukkonen, M. Rahikainen, Tuominen et al. (2000). Students' skills and practices of using ICT: results of a national assessment in Finland. Computers \& Education, 34, 103-117.

Holmes, B., T. Savage and B. Tangney (2000). Innovation in Learning in the Information Society: A Comparative International Study. Retrieved September 22, 2004, from http://odtl.dcu. ie/mirror/crite/CRITEfinal.html

Jonassen, D.H. (1996) Computers in the Classroom: Mindtools for Critical Thinking. New Jersey, Prentice Hall Inc.

Kangro, A., and I. Kangro (2004). Integration of ICT in teacher education and different school subjects in Latvia. Educational Media International, 1 (1), 31-37.

Kurilovas, E. (2003). Tarptautinio tyrimo "IT mokykloje"antrajai daliai (SITES M2) pasibaigus (in Lithuanian, After the 2nd phase of international research (SITES M2) "IT at school"). Retrieved September 22, 2004, from http://www.ipc.1t/21z/mokymas/ mokymopr/elaikr/veidrodis/2003n4.php?id=2\&iid=1\#1

Kurm, M. (2003). Tiger Leap Program in Estonian schools of general education. Retrieved October 5, 2004, from http://www.riigikontroll.ee/upload/failid/ka_7024_tiigrihype_31.03. 2003_lopp.pdf

Lietuvos švietimas 2004. (2004). Lietuvos Respublikos švietimo ir mokslo ministerija. Vilnius, Švietimo aprūpinimo centras (in Lithuanian Lithuanian Education 2004).

Markauskaité, L. (2000). Informacijos technologijos diegimas Lietuvos mokyklose: lūkesčiai ir rezultatai (SITES.M1 rezultatu apžvalga) (in Lithuanian, Implementation of information technologies in Lithuanian schools: expectations and results). Retrieved October 10, 2004, from http://www.ipc.1t/21z/duomenys/tyrimai/sitesm-1/reviu\%20 (apie\%20sites $\div 20 \mathrm{~m}-1 \% 20$ mokyklai) $\cdot \mathrm{pdf}$

Means, B., J. Blando, K. Olson, T. Middleton, C.C. Morocco, A. Remz, et al. (1993). Using technology to Support Education Reform. USA, US Department of Education, Office of Educational Research.

Mokomujų kompiuterinių priemonių naudojimo ir diegimo tyrimas. Ataskaita. (2003). LR švietimo ir mok- 
slo ministerija. Informaciniu technologiju centras. Vilniaus pedagoginis universitetas (in Lithuanian, Research on educational software application and introduction. Report). Retrieved January 8, 2005, from http://www.smm.lt/svietimo_bukle/docs/MK_tyrimas.pdf

Mooij, T., and E. Smeets (2001). Modeling and supporting ICT implementation in secondary schools. Computers and Education, 36, 265-281.

Nacionalinis 4 ir 8 klasés moksleivių pasiekimu tyrimas (2003). Lietuvos švietimo ir mokslo ministerija. Švietimo plètotès centras. Nacionalinis egzaminu centras (in Lithuanian, National research on 4th and 8th formers' achievement)

Neo, K.T. (2003). Using multimedia in a constructivist learning environment in the Malaysian classroom. Australian Journal of Educational Technology, 19 (3). Retrieved October 14, 2004, from http://www.ascilite.org.au/ajet/ajet19/neo.html

Owen, M. (1999). Appropriate and appropriated technology: Technological literacy and educational software standards. Educational Technology \& Society, 2 (4). Retrieved November 16, 2004, from http://ifets.massey.ac.nz/periodical/vol_4_99/martin_owen.html

Ozmon, H.A., S.M. Carver (1996). Filosofiniai ugdymo pagrindai. Vilnius, Leidybos centras (in Lithuanian, Philosophical basics of educations).

Pelgrum, W.J. (2001) Obstacles to the integration of ICT in education: results from a worldwide educational assessment. Computers and Education, 37, 163-178.

Smeets, E., T. Mooij, H. Bamps, A. Bartolomé, J. Lowyck, D. Redmond et al. (1999). The Impact of Information and Communication Technology on the Teacher. Retrieved November 25, 2004, from http://webdoc.ubn.kun.nl/anon/i/impaofina.pdf

UNESCO (1994). Informatics for Secondary Education: A Curriculum for Schools. Paper produced by a working party of the International Federation for Information Processing under the auspices of UNESCO, Paris.

UNESCO (2002). Basic ICT Usage Indicators in Secondary Education in the Baltic and CIS States. Statistical Report UNESCO, Moscow.

P. Pečiuliauskienè is an associate professor in the Department of Education Science at Vilnius Pedagogical University. She lecture on teaching methodology and multimedia instructional development and implementation. Her research interests include improvement of natural science didactics, application of informational technologies in educational practice of natural science subjects as well as distance teaching of physics.

M. Barkauskaitè is professor, a head of the Department of Education Science at Vilnius Pedagogical University, a member of Vilnius Pedagogical University Senate, a chair of the Council of the Faculty of Pedagogy and Psychology as well as the editor-in-chief of the scientific journal "Pedagogika“. Her scientific interests include important issues related to teacher training and application of information technologies in educational practice. 


\section{Kompiuteriniu mokymo programų naudojimas mokant gamtamoksliniu dalyku Lietuvos bendrojo lavinimo mokykloje

\author{
Palmira PEČIULIAUSKIENĖ, Marija BARKAUSKAITĖ
}

Konceptualiai pagrindžiant informacinių technologijų integravimo į edukacinę praktiką raidą, išskiriami keturi etapai: pradinis, taikymo, isiliejimo, kaitos (UNESCO, 1994). Pradiniame etape pagrindinis dėmesys skiriamas kompiuterinei technikai. Antrajame taikymo etape informacinès technologijos pradedamos naudoti daugelio dalykų edukacinèje praktikoje. Šiame etape dabar yra daug pasaulio šaliu - vienos jų tik ižengia į šį etapa, kitos - ji jau užbaigia. Trečiajame etape informacinès technologijos naudojamos visų dalykų edukacinejje praktikoje, isigali integruotas mokymo ir mokymosi požiūris. Ketvirtajame etape mokymasis tampa nenutrūkstamas procesas, pakinta visuomenès požiūris i mokymąsi. Minèti informacinių technologijų integravimo etapai būdingi edukacinei praktikai visų šaliu mokyklose ar kitose ugdymo institucijose.

Šiame straipsnyje, remiantis Lietuvos nacionalinio moksleiviu pasiekimu tyrimo duomenimis, nagrinejami antrojo informacinių technologiju integravimo i edukacinę praktiką ypatumai, siekiama diagnostiniu aspektu ivertinti kompiuteriniu mokymo programu taikymą mokant gamtamokslinių dalykų skirtinguose bendrojo lavinimo mokyklos koncentruose, miesto, rajonu centru, kaimo mokyklose.

Nustatyta, kad kompiuterinès mokymo programos dažniau naudojamos pradinèje mokykloje per pasaulio pažinimo pamokas nei pagrindinèje mokykloje per gamtamokslinio ugdymo pamokas. Pradinėse mokyklose kompiuterinės mokymo programos dažniausiai naudojamos miesto, rečiau - rajonu centrų ir rečiausiai - kaimo mokyklose. Pagrindinėse mokyklose dažniausiai kompiuterinès mokymo programos naudojamos kaimo, rečiausiai - miestų mokyklose. Palyginus kompiuterinių mokymo programų naudojimo procentinius dažnius per skirtingas gamtamokslinių dalyku pamokas, nustatyta, kad dažniausiai kompiuterinès mokymo programos panaudojamos per biologijos pamokas, rečiausiai - per fizikos pamokas. 